\title{
Flora da Usina São José, Igarassu, Pernambuco: Apocynaceae
}

\author{
Flora of the Usina São José, Igarassu, Pernambuco: Apocynaceae
}

\author{
Thales Silva Coutinho1,2 \& Rafael Batista Louzada ${ }^{1}$
}

\begin{abstract}
Resumo
Apocynaceae compõe um grupo de plantas latescentes e está representada por aproximadamente 5.000 espécies em 400 gêneros, com distribuição pantropical. Para o Brasil, estima-se cerca de 77 gêneros e 754 espécies, sendo a Mata Atlântica o domínio de maior diversidade. Para a Mata Atlântica ao norte do Rio São Francisco os trabalhos com foco na família são escassos, limitando-se a listagens florísticas gerais. Desse modo, objetiva-se aqui inventariar e caracterizar morfologicamente as espécies de Apocynaceae nos fragmentos florestais da Usina São José, situada na cidade de Igarassu, Pernambuco. O estudo foi realizado mediante coletas nos fragmentos florestais da área de estudo entre 2015 e 2016, além de consulta a materiais depositados em herbários de referência na região. Foram registradas 17 espécies inseridas em 11 gêneros: Aspidosperma discolor, A. spruceanum, Blepharodon pictum, Ditassa hispida, Hancornia speciosa, Himatanthus bracteatus, Mandevilla hirsuta, M. moricandiana, M. scabra, Matelea ganglinosa, M. orthosioides, Odontadenia lutea, Rauvolfia grandiflora, R. ligustrina, Tabernaemontana flavicans, T. salzmannii e Temnadenia odorifera. São apresentadas chave de identificação, comentários relevantes acerca das espécies e ilustrações.

Palavras-chave: Mata Atlântica, plantas latescentes, Região Nordeste, Rio São Francisco, taxonomia.
\end{abstract}

\begin{abstract}
Apocynaceae comprises a group of lactescent plants and is represented by approximately 5,000 species and 400 genera, with pantropical distribution. In Brazil, it is estimated about 77 genera and 754 species. The Atlantic Forest harbors the most of species of the family. Floristic studies in the northern region of São Francisco River are still scarce, limited to general floristic checklists. Therefore, the main goal of this study was to produce the taxonomic treatment of the species of Apocynaceae of the forests fragments of Usina São José, in the city of Igarassu, Pernambuco. For this study we conducted field work between 2015 and 2016 and we analyzed vouchers deposited in important herbaria from the Brazilian region of Northeast. We found 17 species and 11 genera: Aspidosperma discolor, A. spruceanum, Blepharodon pictum, Ditassa hispida, Hancornia speciosa, Himatanthus bracteatus, Mandevilla hirsuta, M. moricandiana, M. scabra, Matelea ganglinosa, M. orthosioides, Odontadenia lutea, Rauvolfia grandiflora, R. ligustrina, Tabernaemontana flavicans, T. salzmannii and Temnadenia odorifera. The study follows with identification key, relevant comments about the species and illustrations.
\end{abstract}

Key words: Atlantic Forest, lactescent plants; Northeast region; São Francisco river; taxonomy.

\section{Introdução}

Apocynaceae Juss. está inserida na ordem Gentianales (APG IV 2016) e compreende cerca de 5.000 espécies incluídas nos quase 400 gêneros (Rapini 2012), com distribuição predominantemente pantropical/subtropical, com alguns representantes em regiões temperadas (Sennblad \& Bremer 2002). No Brasil, esse número chega a 77 gêneros e 754 espécies, habitando todos os domínios fitogeográficos e com ampla distribuição em todos eles (BFG 2015), no entanto, é no domínio da Mata Atlântica que a família se mostra mais diversa, contando com cerca de 367 espécies (BFG 2015).

A família recebe especial atenção por possuir espécies com importância econômica, destacando o gênero Aspidosperma Mart., que fornece madeira

\footnotetext{
${ }^{1}$ Universidade Federal de Pernambuco, Centro de Biociências, Depto. Botânica, Lab. Morfo-Taxonomia Vegetal, Av. Prof. Moraes Rêgo s/n, Cidade Universitária, 50670-901, Recife, PE, Brasil.

2 Autor para correspondência: thales_scoutinho@hotmail.com
} 
utilizada na carpintaria (Joly 2002). Outras espécies são utilizadas como ornamentais, a exemplo de Nerium L. (oleander), Hoya R. Br. (flor-de-cera) (Sennblad \& Bremer 2002), Allamanda spp. (alamanda, dedal-de-princesa), Catharanthus roseus (L.) G. Don (vinca), Plumeria rubra L. (jasmimmanga) e Thevetia peruviana (Pers.) K. Schum. (chapéu-de-napoleão), no entanto, algumas são tóxicas para o ser humano, e deveriam ser evitadas para cultivo com esta finalidade (Souza \& Lorenzi 2012). Seus representantes são tipicamente laticíferos e produtores de alcalóides e cardenolídeos, alguns dos quais detentores de propriedades medicinais, como as substâncias vincristina e vimblastina extraídas de Catharanthus G. Don, compostos estes amplamente utilizados no tratamento da leucemia (Sennblad \& Bremmer 2002).

No Brasil, os estudos taxonômicos estão concentrados principalmente na Região Sudeste (e.g., Fontella-Pereira et al. 1995; Koch \& Kinoshita 2009; Kinoshita \& Simões 2005; Monguilhott \& Mello-Silva 2008; Matozinhos \& Konno 2011; Rapini et al. 2001, 2003), entretanto, na Região Nordeste estes trabalhos ainda são incipientes, destacando os de Watanabe et al. (2009) na Bahia e Farinaccio et al. (2013) para Sergipe.

Com o intuito de fornecer mais informações sobre a diversidade de Apocynaceae na Floresta Atlântica do nordeste do Brasil, objetivou-se neste trabalho realizar o estudo taxonômico da família no complexo florestal da Usina São José, município de Igarassu, Pernambuco. Além do conhecimento taxonômico e morfológico, são apresentadas descrições, chave de identificação, ilustrações e comentários acerca das espécies.

\section{Material e Métodos}

A área de estudo compreende os fragmentos florestais da Usina São José (USJ), localizada em Pernambuco entre as coordenadas $07^{\circ} 40^{\prime} 21,25^{\prime \prime} \mathrm{e}$

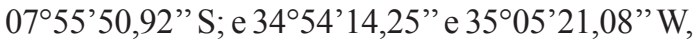
estendendo-se por uma grande faixa no município de Igarassu, além de pequenas áreas dos municípios de Abreu e Lima, Araçoiaba, Itapissuna, Itaquitinga e Goiana, com uma área de $280 \mathrm{~km}^{2}$ (Trindade et al. 2008). A USJ dista aproximadamente $50 \mathrm{~km}$ da cidade de Recife, capital de Pernambuco, imersa em uma matriz de cultivo de cana-de-açúcar (Alves-Araújo et al. 2008) e caracterizada por um clima do tipo As' (Köppen 1936), quente e úmido, com média pluviométrica anual de $1.687 \mathrm{~mm} \mathrm{e}$ temperatura em torno de $24,9{ }^{\circ} \mathrm{C}$ (dados da Usina São José de 1998 a 2006).
Expedições mensais aos fragmentos florestais da USJ foram feitas entre 2015 e 2016, abrangendo sempre a maior área possível, tanto nas bordas de mata quanto em seu interior.

As amostras botânicas foram tratadas segundo metodologia usual em taxonomia vegetal (Mori et al.1985) e depositadas no Herbário Geraldo Mariz (UFP) da Universidade Federal de Pernambuco (UFPE), com duplicatas enviadas aos herbários HUEFS, JPB, IPA, RB e UEC. Informações adicionais foram obtidas mediante análise dos exemplares depositados nos herbários EAC, IPA, JPB, MAC, PEUFR, UFP, UFRN (acrônimos segundo Thiers 2016 [continuamente atualizado]) e HST (Herbário Sérgio Tavares da Universidade Federal Rural de Pernambuco).

As identificações botânicas foram feitas através de consulta a bibliografias especializadas (e.g., Farinaccio et al. 2013; Kinoshita \& Simões 2005; Marcondes-Ferreira 1988; Morales 2005; Rapini 2010), comparação com amostras identificadas por especialistas e análise de fotografias de espécimes-tipos, quando disponíveis. Os hábitats para Usina São José foram classificados segundo Silva et al. (2008). A terminologia morfológica segue recomendações de Harris \& Harris (2011), Radford et al. (1974) e Hickey (1973) para venação foliar. As descrições seguem o padrão para a família Apocynaceae, sendo também observadas particularidades para cada subfamília. Este trabalho segue o modelo para as diversas famílias botânicas já monografadas para a Usina São José (Alves-Araújo \& Alves 2010; Pessoa \& Alves 2012; Maciel \& Alves 2014; Costa-Lima \& Alves 2015; Luna et al. 2016, entre outros).

\section{Resultados e Discussão}

Foram registradas 17 espécies em 11 gêneros nos fragmentos florestais da Usina São José: Odontadenia Benth., Mandevilla Lindl. e Temnadenia Miers. para a subfamília Apocynoideae; Blepharodon Decne., Ditassa R.Br. e Matelea Aubl. para Asclepiadoideae; e Aspidosperma Mart., Hancornia Gomes, Himatanthus Willd. ex Schult., Tabernaemontana L. e Rauvolfia L. em Rauvolfioideae. A subfamília Rauvolfioideae foi a mais representativa em termos de número de espécies, contando com oito, seguida de Apocynoideae com cinco e Asclepiadoideae com quatro. O gênero mais diverso foi Mandevilla com três espécies, seguido de Aspidosperma, Matelea, Rauvolfia e Tabernaemontana com duas, e o restante com apenas uma. 
No geral, as espécies encontradas na área de estudo possuem ampla distribuição na região neotropical, entretanto, destacam-se Himatanthus bracteatus (A.DC.) Woodson, Mandevilla moricandiana (A.DC.) Woodson, Matelea ganglinosa (Vell.) Rapini e Temnadenia odorifera (Vell.) J.F. Morales, por serem endêmicas do Brasil. Matelea ganglinosa (Vell.) Rapini e M. orthosioides (E.Fourn.) Fontella representam novos registros para a USJ com base em Alves et al. (2013). Odontadenia lutea (Vell.) Markgr. é um novo registro para
Pernambuco de acordo com BFG (2015). A maioria das espécies ocorre principalmente nos domínios da Amazônia, Caatinga, Cerrado e Mata Atlântica, no entanto, Himatanthus bracteatus, Rauvolfia grandiflora Mart. ex. A.DC. e Temnadenia odorifera são endêmicas da Mata Atlântica.

Das 17 espécies da área, 52,94\% (nove spp.) são compostas por trepadeiras, $35,29 \%$ (seis spp.) são árvores e os $11,76 \%$ (duas spp.) restantes representados por arbustos, com o total das espécies ocorrendo em sua maioria na bordas de mata.

\section{Chave de identificação das espécies de Apocynaceae da Usina São José}

1. Trepadeiras; anteras adnatas à cabeça estigmática.

2. Sépalas alternas às pétalas; presença de corona; corola rotácea.

3. Ramos glabros, glabrescentes ou tomentosos; corona simples.

4. Lâmina foliar coriácea; corona cotiliforme Blepharodon pictum

4'. Lâmina foliar membranácea a cartácea; corona anelar.

5. Lâmina foliar pubescente, cordiforme; corona conspícua .... Matelea ganglinosa

5'. Lâmina foliar glabra, elíptica; corona inconspícua Matelea orthosioides

3'. Ramos pilosos a híspidos; corona dupla Ditassa hispida

2'. Sépalas opostas às pétalas; ausência de corona; corola infundibuliforme ou hipocrateriforme.

6. Lâmina foliar com coléteres; cabeça estigmática umbraculiforme; anteras dorsalmente glabras.

7. Corola amarela; coléteres ao longo da nervura primária na face adaxial da lâmina foliar; lâmina foliar elíptica ou estreito-elíptica.

8. Fauce da corola vermelha; sépalas 5,4-6,2 $\mathrm{mm}$ compr., lanceoladas; frutos hirsutos Mandevilla hirsuta

8'. Fauce da corola rajada em vermelho-alaranjada ou amarela; sépalas ca. 2,2 mm compr., triangulares; frutos glabros Mandevilla scabra

7'. Corola cor-de-rosa; coléteres restritos à base da lâmina foliar na nervura primária da face adaxial; lâmina foliar obdeltóide Mandevilla moricandiana

6'. Lâmina foliar sem coléteres; cabeça estigmática fusiforme; anteras dorsalmente puberulentas ou pubescentes.

9. Ramos glabros, lenticelados; lâmina foliar elíptica; corola infundibuliforme, alva ....... Odontadenia lutea

9'. Ramos glabrescentes a estrigosos, sem lenticelas; lâmina foliar ovada; corola hipocrateriforme, lilás a rosada Temnadenia odorifera

1'. Árvores, arvoretas ou arbustos; anteras livres da cabeça estigmática.

10. Folhas alternas.

11. Coléteres intrapeciolares presentes; brácteas pelatóides; sépalas 1-4; ovário semi-ínfero ... Himatanthus bracteatus

11'. Coléteres intrapeciolares ausentes; brácteas escariosas; sépalas-5; ovário súpero.

12. Ramos lenticelados; látex alvo; lobos da corola elípticos; ovário lanuloso Aspidosperma discolor

12'. Ramos sem lenticelas; látex avermelhado; lobos da colora linear-lanceolados; ovário glabro Aspidosperma spruceanum

10'. Folhas opostas ou verticiladas.

13. Lâmina foliar estreito-elíptica ou oblonga; nectário ausente.

14. Venação craspedódroma; coléteres ausentes na base da face adaxial das sépalas Hancornia speciosa 
14'. Venação camptódroma ou broquidódroma; coléteres presentes na base da face adaxial das sépalas. 15. Pecíolo $\leq 0,9 \mathrm{~cm}$ compr.; coléteres intrapeciolares ausentes; inflorescências laterais; lacínios do cálice eretos Tabernaemontana flavicans

15'. Pecíolo >0,9 cm compr.; coléteres intrapeciolares presentes; inflorescências terminais; lacínios do cálice reflexos Tabernaemontana salzmannii

13'. Lâmina foliar oblanceolada a elíptica; nectário presente.

16. Folhas 3 por nó, dispostas ao longo dos ramos; coléteres ao longo dos pecíolos

Rauvolfia ligustrina

16'. Folhas 4 por nó, dispostas no ápice dos ramos; ausência de coléteres nos pecíolos Rauvolfia grandiflora

\section{Tratamento taxonômico} Apocynaceae Juss.

Árvores, arvoretas, arbustos ou trepadeiras. Látex alvo, eventualmente vermelho ou incolor. Folhas alternas, opostas ou verticiladas, distribuídas ao longo ou no ápice dos ramos. Cálice gamossépalo, 5-mero, raramente reduzido ou ausente. Corola gamopétala, 5-mera; corona ausente ou presente. Anteras adnatas ou não à cabeça estigmática. Ovário súpero, raramente semi-ínfero (Himatanthus bracteatus). Frutos folículos, bagas ou drupas.

Aspidosperma Mart., Mart. \& Zucc., Flora 7(1, Beil. 4): 135. 1824.

Árvores, látex alvo ou vermelho, abundante. Ramos glabros, lenticelados ou não, coléteres inter e intrapeciolares ausentes. Folhas alternas; lâmina sem coléteres; venação broquidódroma ou eucamptódroma. Brácteas escariosas. Sépalas sem coléteres. Corola hipocrateriforme. Estames livres da cabeça estigmática; anteras de base cordada, dorsalmente glabras. Ovário globoso, glabro ou lanuloso; nectário ausente; cabeça estigmática fusiforme, apêndices apicais-2.

1. Aspidosperma discolor A. DC., Prodr. 8: 398. 1844.

Fig. 1a-d

Árvores 2-20 m alt., látex alvo. Ramos com lenticelas concentradas principalmente no ápice. Pecíolo 0,5-1 cm compr., glabros. Lâmina foliar 9-17 × 4,4-6,6 cm, elíptica, coriácea, base cuneada, algumas vezes revolutas aparentando base atenuada, margens levemente revolutas, ápice retuso a obtuso, face adaxial glabra, abaxial esparsamente pubescente, venação broquidódroma. Tirsos laterais, 6-10 flores; brácteas ca. 1,5 × $1 \mathrm{~mm}$, pubescentes; pedúnculo $1-1,5 \mathrm{~cm}$ compr., puberulento; pedicelo $0,3-0,4 \mathrm{~cm}$ compr., pubescente. Sépalas ca. 1,8 $\times 1,5 \mathrm{~mm}$, amplamente ovadas, ápice agudo, externamente puberulentas a pubescentes. Corola creme, pubescente; tubo ca. $6,5 \times 2-2,5 \mathrm{~mm}$; lobos ca. 2,5 × 1-1,2 mm, elípticos. Anteras ca. 1,2 ×0,4 $\mathrm{mm}$. Ovário ca. $1,5 \times 1,5 \mathrm{~mm}$, lanuloso; estilete ca. 2,5 mm compr.; cabeça estigmática ca. $0,8 \mathrm{~mm}$ compr. Frutos não observados.

Material examinado: Mata da Usina São José, est., H.C.H. Silva 124 et al. (PEUFR).

Material adicional examinado: BRASIL. PERNAMBUCO: Recife, Horto de Dois Irmãos, 20.XI.2008, bf. e fl., T.V. Lima (UFP 62554).

Distribui-se pela Venezuela, Guianas e Brasil (Marcondes-Ferreira 1998), no Norte, Nordeste, Centro-Oeste e Sudeste, habitando os domínios da Amazônia, Caatinga, Cerrado e Mata Atlântica (BFG 2015). Na USJ Aspidosperma discolor ocorre em bordas, tabuleiros e sítios ripários, e pode ser distinguida de A. spruceanum pelo látex alvo (vs. vermelho), base revoluta da lâmina foliar dando um aspecto de base atenuada ( $v s$. base não revoluta) e pela corola pubescente com lobos elípticos (vs. corola glabra com lobos linear-lanceolados).

2. Aspidosperma spruceanum Benth. ex Müll. Arg., Fl. bras. 6(1): 52-53. $1860 . \quad$ Fig. 1e Árvores $12-18 \mathrm{~m}$ alt., látex vermelho. Ramos não lenticelados. Pecíolo 2,5-3,2 cm compr., glabro. Lâmina foliar ca. $15 \times 4,6-5 \mathrm{~cm}$, elíptica, cartácea a coriácea, base cuneada, margens levemente onduladas, ápice acuminado, glabra em ambas as faces; venação eucamptódroma. Tirsos terminais, ca. 60 flores; bráctea 1,8-4 × $1 \mathrm{~mm}$, pubescente; pedúnculo ca. $2,1 \mathrm{~cm}$ compr., glabro; pedicelo $0,2-0,3 \mathrm{~cm}$ compr., pubescente. Sépalas ca. 2,5 $\times 1,5 \mathrm{~mm}$, elípticas, ápice agudo, externamente pubescentes. Corola alva a amarelada, glabra; tubo ca. $5 \times 2 \mathrm{~mm}$; lobos ca. $3 \times 0,5 \mathrm{~mm}$, linearlanceolados, torcidos entre si ou livres. Anteras ca. 1,2 ×0,4 mm. Ovário ca. $1,1 \times 1 \mathrm{~mm}$, glabro; estilete ca. $1,4 \mathrm{~mm}$; cabeça estigmática $0,4 \mathrm{~mm}$ compr. Frutos não observados.

Material examinado: Mata da Usina São José, est., H.C.H. Silva et al. 151 (PEUFR); Mata de Piedade, 29.VIII.2003, est., H.C.H. Silva \& J.S. Silva 315 (PEUFR). 


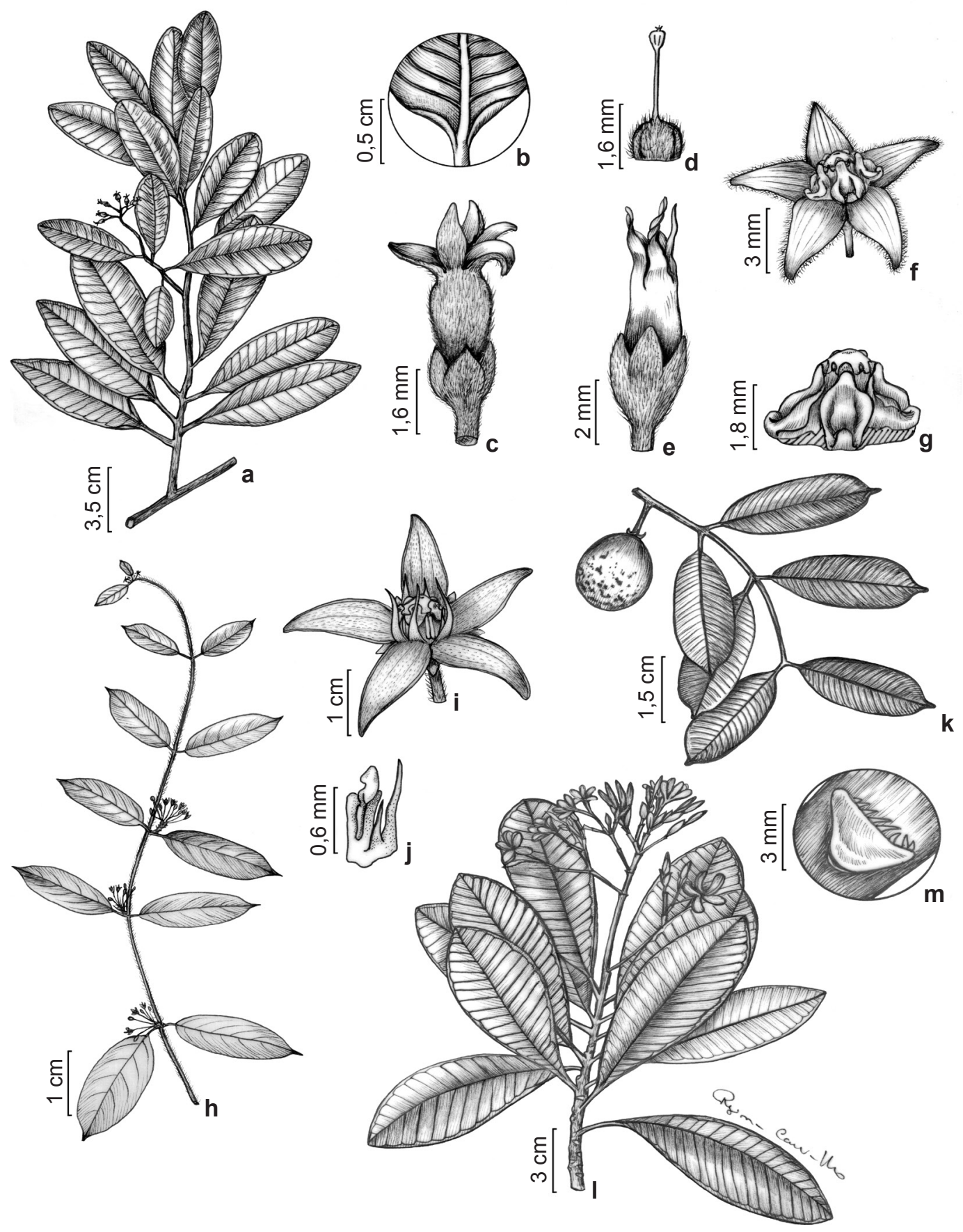

Figura 1 - a-d. Aspidosperma discolor - a. hábito com flores; b. detalhe da lâmina foliar mostrando a base revoluta; c. flor; d. carpelo. e. Aspidosperma spruceanum - flor. f-g. Blepharodon pictum - f. flor; g. corona cotiliforme e ginostégio. h-j. Ditassa hispida - h. hábito com flores; i. flor; j. corona. k. Hancornia speciosa - ramo com folhas e fruto. 1-m. Himatanthus bracteatus - 1. hábito com flores; $\mathrm{m}$. detalhe dos coléteres intrapeciolares. (a,c-d. T.V Lima s.n. [UFP 62554]; b. H.C.H. 124; e. T. Leão 927; f. D. Cavalcanti 627; h-j. J.D. García G 942; k. A. Alves-Araújo 896; 1-m. T.S. Coutinho 90).

Figure 1 - a-d. Aspidosperma discolor - a. habit with flowers; b. detail of the leaf blade showing the revolute base; c. flower; d. carpel. e. Aspidosperma spruceanum - flower. f-g. Blepharodon pictum - f. flower; g. cotyliform corona and gynostegium. $\mathrm{h}-\mathrm{j}$. Ditassa hispida $\mathrm{h}$. habit with flowers; i. flower; j. corona. k. Hancornia speciosa - branch with leaves and fruit. 1-m. Himatanthus bracteatus - 1. habit with flowers; m. detail of the intrapetiolar colleters. (a,c-d. T.V Lima s.n. [UFP 62554]; b. H.C.H. 124; e. T. Leão 927; f. D. Cavalcanti 627; h-j. J.D. García G 942; k. A. Alves-Araújo 896; 1-m. T.S. Coutinho 90). 
Material adicional examinado: BRASIL. PERNAMBUCO: Lagoa dos Gatos, RPPN Pedra D’Anta, 25.I.2007, fl., T. Leão 927 (UFP).

Distribui-se desde o México até o Brasil (Marcondes-Ferreira 1988; Govaerts \& Leeuwenberg 2016), nas regiões Norte, Nordeste, Centro-Oeste e Sudeste, na Amazônia, Cerrado e Mata Atlântica (BFG 2015). Na USJ Aspidosperma spruceanum ocorre em bordas de mata e pode ser distinguida de $A$. discolor pelo látex vermelho ( $v S$. alvo) e corola glabra com lobos linear-lanceolados (vs. corola pubescente com lobos lanceolados).

\section{Blepharodon pictum (Vahl) W.D. Stevens,} Novon 10(3): 242. 2000.

Fig. $1 f-g$

Trepadeiras herbáceas; látex alvo. Ramos glabros, não lenticelados, coléteres inter e intrapeciolares presentes. Folhas opostas; pecíolo ca. $0,6 \mathrm{~cm}$ compr., glabro a glabrescente; lâmina 2,6-4,9 × 2-2,4 cm, elíptica, coriácea, base arredondada, margens revolutas, eventualmente ciliadas, ápice obtuso a cuspidado, glabra em ambas as faces, coléteres- 2 na base da lâmina na face adaxial; venação broquidódroma. Cimeiras laterais, 2-4 flores; bráctea escariosa, ca. $1 \times 0,5$ $\mathrm{mm}$, glabra; pedúnculo $0,3-0,4 \mathrm{~cm}$ compr., glabro; pedicelo 1,3-1,6 cm compr., glabro. Sépalas 1,8-2 $\times 1,4-1,5 \mathrm{~mm}$, ovadas, ápice agudo, externamente glabras, coléteres alternos na base da face interna. Corola rotácea, esverdeada, ciliada apenas nos lobos; tubo ca. 0,5 mm compr.; lobos 6-7 $\times$ 3-5,5 mm, largo-ovados. Corona simples, ca. $3,2 \mathrm{~mm}$ compr., cotiliforme. Anteras ca. $3,5 \mathrm{~mm}$ compr., apêndice membranáceo ca. 1,1 × 1,7 mm. Retináculo ca. 0,4 mm compr.; caudículas ca. 0,2 $\mathrm{mm}$ compr.; polínias ca. $0,4 \times 0,4 \mathrm{~mm}$, inseridas subterminalmente às caudículas. Ovário 1,2-1,6 mm compr., ovoide, glabro; nectário ausente; ginostégio ca. $1 \mathrm{~mm}$ compr., ápice tenuamente mamilado. Frutos folículos, ca. $6 \times 2 \mathrm{~cm}$, glabros. Sementes comosas, ca. $0,5 \times 0,2 \mathrm{~cm}$, coma alva.

Material examinado: Mata dos Macacos, 6.VII.2007, fl. e fr., J.S. Marques \& N.A. Albuquerque 181 (IPA); Mata de Pezinho, 23.V.2007, fr., J.S. Marques \& N.A. Albuquerque 116 (UFP).

Material adicional examinado: BRASIL. PERNAMBUCO: Goiana, RPPN Fazenda Tabatinga, 29.XI.2011, fl. e fr., D. Cavalcanti et al. 627 (UFP).

Distribui-se pelo Paraguai, Venezuela, Guiana, Guiana Francesa, Suriname, Colômbia, Brasil e Paraguai (Rapini 2010). No Brasil Blepharodon pictum ocorre em praticamente todo o país, exceto no Piauí, Santa Catarina e Rio Grande do Sul, nos domínios da Amazônia, Caatinga, Cerrado e Mata
Atlântica (BFG 2015). Na USJ a espécie ocorre em bordas de mata e pode ser reconhecida pelas flores de corola esverdeada, de margens ciliadas e corona simples e cotiliforme.

4. Ditassa hispida (Vell.) Fontella, Bradea 3(2): 5. 1979.

Fig. $1 \mathrm{~h}-\mathrm{j}$

Trepadeiras lenhosas; látex alvo. Ramos pilosos a híspidos, coléteres interpeciolares ausentes, intrapeciolares presentes. Folhas opostas; pecíolo $0,3-0,7 \mathrm{~cm}$, esparsamente piloso; lâmina 1,6-3,3 $\times 0,6-1,1 \mathrm{~cm}$, estreito-elíptica, membranácea, base cuneada, margens levemente revolutas, ápice acuminado, pilosas em ambas as faces, coléteres- 2 na base da lâmina na face adaxial; venação broquidódroma. Cimeiras umbeliformes axilares, 4-10 flores; bráctea escariosa, $0,7-1 \times 0,3-0,7$ $\mathrm{mm}$, glabrescente a pilosa; pedúnculo $0,3-0,4 \mathrm{~cm}$ compr., glabro a glabrescente; pedicelo $0,3-0,5$ $\mathrm{cm}$, glabro a glabrescente. Sépalas 1-1,2 × 0,6-1 $\mathrm{mm}$, ovadas, ápice agudo, externamente pilosas, coléteres alternos na base da face interna. Corola rotácea, alva, glabra, pubescente nos lobos; tubo ca. $0,5 \mathrm{~mm}$ compr.; lobos 3-3,5 $\times 1 \mathrm{~mm}$, lanceolados. Corona dupla; segmentos externos ca. 1,2 $\times 0,4 \mathrm{~mm}$, lanceolados; segmentos internos ca. 0,5 ×0,2 mm, lanceolados. Anteras 0,9-1 mm compr., apêndice membranáceo ca. $0,3 \times 0,6 \mathrm{~cm}$, transversalmente estreito-elípticos. Retináculo ca. $0,3 \mathrm{~mm}$ compr.; caudículas ca. 0,1 mm compr.; polínias $0,3-0,4 \times$ $0,1 \mathrm{~mm}$, inseridas subapicalmente às caudículas. Ovário ca. $0,6 \times 0,5 \mathrm{~mm}$, ovoide, glabro; nectário ausente; cabeça estigmática ca. $0,4 \mathrm{~mm}$ compr., ápice tenuamente mamilado. Frutos não observados. Material examinado: Mata de Pezinho, 8.III.2009, fl., J.D. García G. et al. 942 (JPB, UFP); 9.V.2007, fl., J.S. Marques \& N.A. Albuquerque 117 (IPA).

Distribui-se pela Guiana, Guiana Francesa, Argentina e Brasil, na Região Norte, Nordeste, Sudeste e Sul (Rapini 2010; BFG 2015). Na área de estudo, Ditassa hispida é encontrada em bordas de mata e pode ser reconhecida por seus ramos pilosos a híspidos e flores com corona com segmentos interno e externo lanceolados.

5. Hancornia speciosa Gomes, Mem. Math. Phis. Acad. Real Sci. Lisboa 2: 1, pl. 1. 1803. Fig. 1k Árvores 5-7 m alt.; látex alvo. Ramos glabros, coléteres interpeciolares ausentes, intrapeciolares presentes. Folhas opostas, distribuídas ao longo dos ramos; pecíolo $0,6-1,1 \mathrm{~cm}$, glabro; lâmina 3,6-5,1 $\times 1,7-2,5 \mathrm{~cm}$, estreito-elíptica a oblonga, cartácea, base arredonda a cuneada, margens levemente 
revolutas, ápice cuspidado, glabra em ambas as faces, coléteres ausentes; venação craspedódroma. Cimeiras terminais, 2-3 flores; bráctea escariosa, $1-1,5 \times 0,5 \mathrm{~mm}$, esparsamente puberulenta; pedúnculo ca. $0,2 \mathrm{~cm}$ compr., glabro a glabrescente; pedicelo 0,5-0,9 cm compr., glabrescente. Sépalas ca. 1,8 × 1,4 mm, ovadas, ápice agudo a acuminado, externamente pubescentes, coléteres ausentes. Corola hipocrateriforme, glabra, alva; tubo $25-31 \mathrm{~mm}$ compr.; lobos ca. $10 \times 2 \mathrm{~mm}$, lanceolados, glabros. Estames livres da cabeça estigmática; anteras ca. 2,5 mm compr., glabras, base cordada. Ovário 0,9-1 × 0,9 mm compr., ovoide, glabro; nectário ausente; estilete ca. 4,9 cm compr.; cabeça estigmática ca. $2 \mathrm{~mm}$ compr., cilíndrica, apêndices apicais-2. Fruto baga, 2-3,2 $\times 1,4-3 \mathrm{~cm}$, globoso, glabro.

Material examinado: Mata de Zambana, 14.II.2008, fr., A. Alves-Araújo \& J.S. Marques 859 (UFP); 11.III.2008, fr., J.S. Marques \& A. Alves-Araújo 317 (IPA); 14.III.2008, fr., A. Alves-Araújo et al. 896 (UFP). Material adicional examinado: BRASIL. PERNAMBUCO: Ipojuca, Maracaípe, RPPN Nossa Senhora do Oiteiro de Maracaípe, 13.IV.2006, fl., $Y$. Melo et al. 66 (UFP).

Ocorre no Brasil, Peru e Paraguai (Govaerts $\&$ Leeuwenberg 2016). No Brasil Hancornia speciosa ocorre em praticamente todo o país, exceto em Roraima, Acre, Santa Catarina e Rio Grande do Sul, habitando os domínios da Amazônia, Caatinga, Cerrado e Mata Atlântica (BFG 2015). Na USJ a espécie ocorre em bordas de mata e pode ser reconhecida por suas folhas de venação craspedódroma, corola hipocrateriforme alva e fruto tipo baga. A espécie é popularmente conhecida como mangaba, sendo seus frutos comestíveis e de sabor adocicado.

6. Himatanthus bracteatus (A. DC) Woodson, Ann. Missouri Bot. Gard. 25(1): 200. 1938 [1937].

Fig. 11-m

Arvoretas ou árvores 5-7 m alt.; látex alvo. Ramos glabros, lenticelas ausentes, coléteres interpeciolares ausentes, intrapeciolares presentes. Folhas alternas, congestas no ápice; pecíolo 1-3 cm compr., glabro; lâmina 12,1-19,5 × 5-6,2 $\mathrm{cm}$, obovada, coriácea, base cuneada a atenuada, margens planas, ápice cuspidado a arredondado, glabra em ambas as faces, coléteres ausentes; venação broquidódroma. Tirsos terminais, 10-35 flores; pedúnculo 0,3-6,5 cm compr., glabro; bráctea petalóide, $2,7-3,3 \mathrm{~cm}$, glabra, alva, coléteres na base; pedicelo $0,5-0,9 \mathrm{~cm}$ compr., glabro. Sépalas- 1 a 4 ou ausentes, $0,5-5 \times 0,1-1,5$ $\mathrm{mm}$, externamente glabras, coléteres ausentes. Corola hipocrateriforme, glabra, alva, fauce amarela; tubo 20-30 mm compr.; lobos 23-35 mm compr., obovados. Estames livres da cabeça estigmática; anteras 2,3-3,2 mm compr., glabras, base subcordada. Ovário semi-ínfero, 1,6-1,8 × 1,5 $\mathrm{mm}$, ovoide, glabro; nectário ausente; estilete ca. 2 mm compr.; cabeça estigmática ca. $0,5 \mathrm{~mm}$ compr., dilatada, apêndices apicais-2. Fruto folículo, 18-20 $\times 4 \mathrm{~cm}$, glabro. Sementes aladas, $2-2,5 \mathrm{~cm}$ compr., alas membranáceas.

Material examinado selecionado: Córrego do Urubu, 17.IV.2008, f1., L.M. Nascimento et al. 671 (UFP); Engenho Campinas, 19.XI.2015, fr., T.S. Coutinho et al. 91 (UFP); Mata de Chave, 28.I.2016, fl., T.S. Coutinho et al. 129 (UFP); Mata de BR, 28.VIII.2008, fl., P.G.A. Mendes et al. 43 (UFP); Mata do Cabus, 1.II.2007, fl., N.A. Albuquerque et al. 201 (IPA); Mata dos Macacos, 4.VIII.2015, fr., T.S. Coutinho et al. 28 (UFP); Mata de Pezinho, 27.X.2008, fr., T.L. Costa 10 (UFP); Mata de Piedade, 24.I.2008, fl., K.D. Rocha \& A.C.B. Lins e Silva 138 (EAC, HST, UFRN); Mata de Timóteo, 29.XII.2008, fl., L.V. Cunha 313 (HST, IPA); Mata da Usina São José, 26.II.2003, fl., A. Melquíades \& G.J. Bezerra 62 (PEUFR); Mata das Vespas, 24.II.2008, fl., P.Y. Ojima 114 (UFP); Mata de Zambana, 4.X.2005, fr., J.F. Silva Júnior et al. 09 (PEUFR).

Endêmica da Mata Atlântica do Brasil, onde ocorre no Nordeste e Sudeste (Koch et al. 2015). Na USJ Himatanthus bracteatus ocorre em bordas e interior de mata, em hábitats de tabuleiro, e é reconhecida por suas brácteas petalóides alvas (única Apocynaceae na USJ com esta característica), e flores vistosas, alvas com ovário semi-ínfero. A espécie é amplamente distribuída na área de estudo, sendo encontrada em todos os fragmentos estudados.

Mandevilla Lindl., Edwards's Bot. Reg. 26: pl. 7. 1840. nom cons.

Trepadeiras herbáceas ou lenhosas; látex alvo. Ramos não lenticelados, coléteres inter e intrapeciolares presentes. Folhas opostas, discolores; lâmina com coléteres na base ou ao longo da nervura primária da face adaxial; venação broquidódroma. Brácteas escariosas. Sépalas com coléteres opostos na base da face adaxial. Corola infundibuliforme. Estames adnatos à cabeça estigmática; anteras de base cordada. Ovário ovoide, glabro; nectários-5, anelares ou apenas 2; cabeça estigmática umbraculiforme, apêndices apicais-2. 
7. Mandevilla hirsuta (Rich.) K. Schum., Nat. Pflanzenfam. 4(2): 171. 1895.

Fig. 2a-b

Trepadeiras lenhosas. Ramos híspidos ou hirsutos. Pecíolo 0,4-2,6 cm compr., híspido. Lâmina foliar 7,4-15,5 × 3-8,3 cm, estreitoelíptica, cartácea, base cordada, margens planas, ápice acuminado a cuspidado ou longo-acuminado, face adaxial estrigosa ou hirsuta, abaxial híspida a tomentosa, por vezes serícea, coléteres ao longo da nervura primária. Racemos axilares, 6-10 flores; bráctea 7,2-8,5 × $2 \mathrm{~mm}$, pilosa; pedúnculo $1-1,5 \mathrm{~cm}$ compr., piloso; pedicelo 0,5-0,7 cm compr., piloso. Sépalas 5,4-6,2 × 1-1,5 mm, lanceoladas, ápice agudo, externamente pilosas. Corola amarela, fauce totalmente vermelha, híspida; tubo inferior 13-16 $\times 3-4 \mathrm{~mm}$ compr.; tubo superior 30-35 × 6-8 mm compr.; lobos 13-16 × $14 \mathrm{~mm}$, orbiculares. Anteras 4,5-5 × 1,5 mm. Ovário 1,8-2 × $2 \mathrm{~mm}$; nectários-5, 1,5-2 mm compr., anelares com lobos inconspícuos; estilete 34-35 mm compr.; cabeça estigmática ca. 1,7 mm compr. Frutos folículos-2, 5,3-8 × 0,2-0,4 cm compr., hirsutos, unidos ao ápice.

Material examinado: Mata de Chave, 28.I.2016, T.S. Coutinho et al. 127 (UFP); 28.I.2016, fl., T.S. Coutinho et al. 128 (UFP); Mata de Cruzinha, 12.III.2009, fr., J.D. García-González et al. 985 (JPB); Mata dos Macacos, 4.VIII.2015, fl., T.S. Coutinho et al. 27 (UFP); Mata de Zambana, 18.X.2007, fl. e fr., A. Alves-Araújo et al. 650 (UFP); 22.12.2007, fl. e fr., A. Melo et al. 207 (UFP); 10.IX.2015, fl., T.S. Coutinho et al. 76 (UFP).

Ocorre desde o norte do México até o Paraguai (Morales 2007; Govaerts \& Leeuwenberg 2016). No Brasil ocorre em praticamente todo o país, com exceção de Santa Catarina e Rio Grande do Sul, habitando a Amazônia, Caatinga, Cerrado e Mata Atlântica (Koch et al. 2015). Na USJ Mandevilla hirsuta ocorre sempre em bordas de mata, sendo encontrada na maioria dos fragmentos estudados. A espécie é muito semelhante a Mandevilla scabra, diferindo principalmente pelas sépalas maiores $(5,4-6,2$ vs. ca. $2,2 \mathrm{~mm}$ compr.) e pelos frutos híspidos (vs. glabros).

8. Mandevilla moricandiana (A. DC.) Woodson, Ann. Missouri Bot. Gard. 20(4): 705. 1933.

Fig. 2c-e

Trepadeiras lenhosas. Ramos setulosos. Pecíolo 0,4-0,9 cm, escabro. Lâmina foliar 2,2-3,6 $\times 2-2,4 \mathrm{~cm}$, obdeltoide, coriácea, base cuneada, margens levemente revolutas, ápice cuspidado, glabra em ambas as faces, coléteres- 2 na base da lâmina. Racemos laterais ou terminais, 2-6 flores; bráctea ca. $2 \times 0,8 \mathrm{~mm}$, glabra; pedúnculo 2-2,5 cm compr., glabro; pedicelo $0,6-1,1 \mathrm{~cm}$ compr., glabro. Sépalas 5-6 × 1-1,5 mm, lanceoladas, ápice acuminado, externamente glabras. Corola rosa, fauce amarela, glabra; tubo inferior ca. 16 $\times 3 \mathrm{~mm}$; tubo superior ca. $18 \times 8 \mathrm{~mm}$; lobos 25 $\times 28 \mathrm{~mm}$, orbiculares. Anteras ca. $7 \mathrm{~mm}$ compr. Ovário 1-1,2 × 1,2, ovoide; nectários-2, ca. 1 mm compr., alternos aos carpelos; estilete ca. 15 $\mathrm{mm}$ compr.; cabeça estigmática ca. $2 \mathrm{~mm}$ compr. Frutos folículos, 9,5-10,5 cm, glabros, divergentes. Sementes não observadas.

Material examinado: Mata de Zambana, 4.IX.2007, fl., A. Alves-Araújo et al. 553 (UFP); 4.IX.2007, fl. e fr., N.A. Albuquerque 462 (IPA).

Material adicional examinado: BRASIL. SERGIPE: Pirambu, RPPN Lagoa Encantada do Morro da Lucrécia, 2.III.2016, fl., L. Albuquerque et al. 19 (UFP).

Endêmica do Brasil (BFG 2015; Govaerts \& Leeuwenberg 2016), ocorrendo no Nordeste e no estado do Rio de Janeiro na Região Sudeste, na Caatinga, Cerrado e Mata Atlântica (BFG 2015). Na USJ Mandevilla moricandiana ocorre em bordas de mata e pode ser diferenciada das demais espécies de Mandevilla da área pelos coléteres foliares restritos à base da lâmina na face adaxial (vs. ao longo da nervura primária), pelas folhas obdeltóides ( $v s$. elípticas) e pelas flores de corola rosada ( $v s$. amarelas).

9. Mandevilla scabra (Hoffmanns. ex Roem. \& Schult.) K. Schum., Nat. Pflanzenfam. 4(2): 171. 1895.

Fig. 2f-g

Trepadeiras herbáceas. Ramos glabros ou glabrescentes. Pecíolo $0,5-1,1 \mathrm{~cm}$ compr., piloso. Lâmina foliar $5,7-8,5 \times 2,5-4,8 \mathrm{~cm}$, elíptica, membranácea a cartácea, base cordada, margens levemente revolutas, ápice acuminado, face adaxial glabra a pilosa, por vezes pubescente, face abaxial escabra ou pubescente, coléteres ao longo da nervura primária. Racemos axilares, 12-23 flores; pedúnculo 0,8-4 cm compr., glabrescente ou piloso; bráctea 2-3 $\times 1 \mathrm{~mm}$ compr., pilosa; pedicelo 2,5-3 mm compr., glabrescente. Sépalas ca. 2,2 $\times$ $1,2 \mathrm{~mm}$, triangulares, ápice acuminado, glabras externamente. Corola amarela, fauce amarela ou rajada em vermelho a alaranjado, glabrescente; tubo inferior $2-3 \times 0,2 \mathrm{~cm}$ compr.; tubo superior 17-20 × 9-18 mm; lobos ca. $15 \times 15 \mathrm{~mm}$, largoovados ou orbiculares. Anteras 5,5-5,8 mm compr. Ovário 1,1-1,5 × 1,7 mm, glabro; nectários-5, 1-1,5 mm, anelares, levemente lobados; estilete ca. $23 \mathrm{~mm}$ compr.; cabeça estigmática $2-3 \mathrm{~mm}$ compr. Frutos folículos-2, 10-14 × 2 cm compr., glabros, unidos ao ápice. 

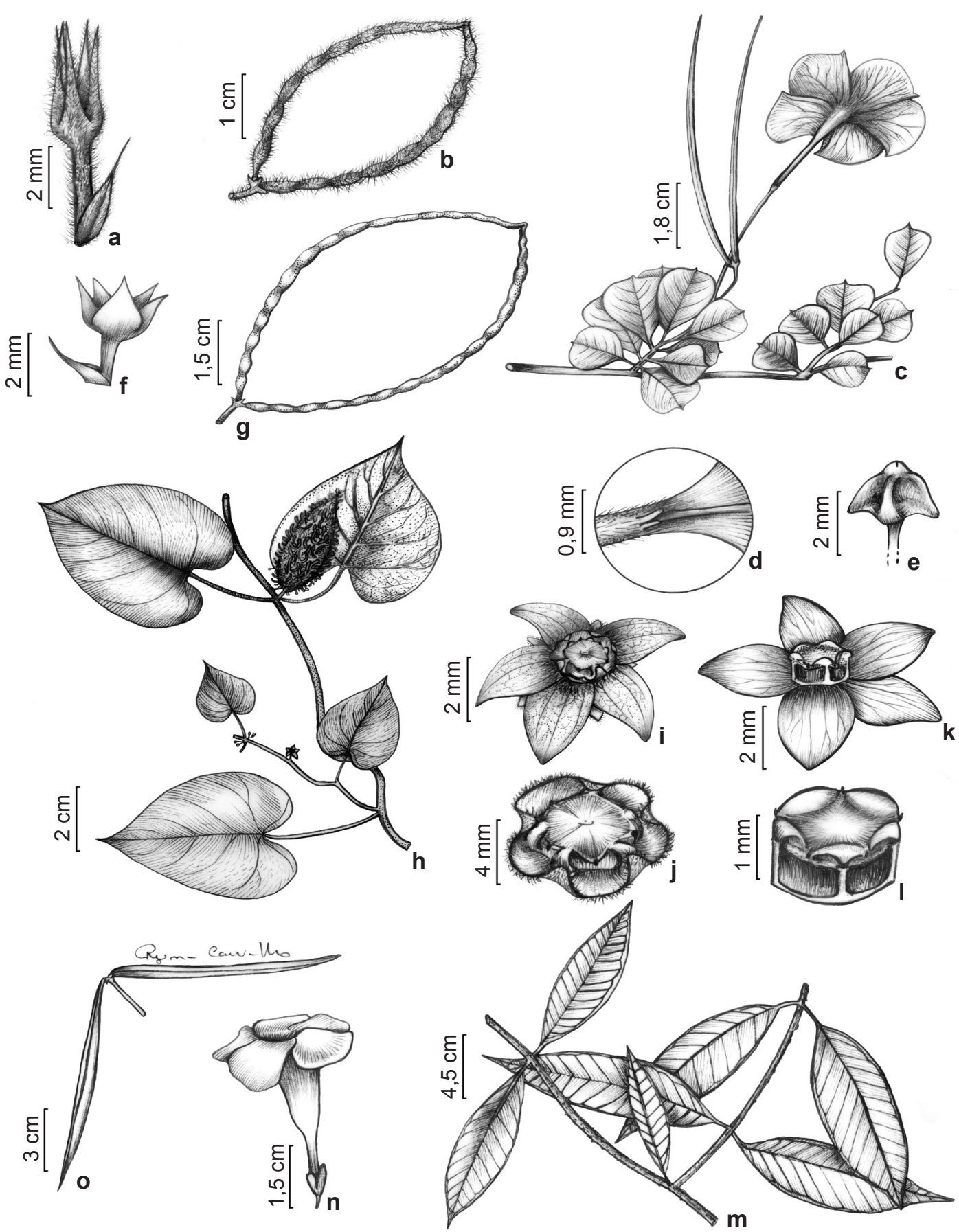

Figura 2 - a-b. Mandevilla hirsuta - a. bráctea e cálice; b. fruto. c-e. Mandevilla moricandiana - c. hábito com flores e frutos; d. detalhe da base da lâmina foliar com coléteres; e. cabeça estigmática. f-g. Mandevilla scabra-f. bráctea e cálice; g. fruto. h-j. Matelea ganglinosa - h. hábito com flores e fruto; i. flor; j. corona e ginostégio. k-1. Matelea orthosioides - k. flor; 1. corona e ginostégio. m-o. Odontadenia lutea - m. hábito; n. flor; o. fruto. (a-b. T.S. Coutinho 27; c-e. N.A. Albuquerque 426; f-g. T.S. Coutinho 143; h-j. T.S. Coutinho 78; k-1. D. Araújo 1980; m. J.D. García G. 1467; n-o. D. Cavalcanti 609). Figure 2 - a-b. Mandevilla hirsuta - a. bract and calyx; b. fruit. c-e. Mandevilla moricandiana - c. habit with flower and fruit; d. detail of the base of leaf blade with colleters; e. style-head. f-g. Mandevilla scabra - f. bract and calyx; g. fruit. h-j. Matelea ganglinosa - h. habit with flowers and fruit; i. flower; j. corona and gynostegium. k-l. Matelea orthosioides - k. flower; l. corona and gynostegium. m-o. Odontadenia lutea - m. habit; n. flower; o. fruit. (a-b. T.S. Coutinho 27; c-e. N.A. Albuquerque 426; f-g. T.S. Coutinho 143; h-j. T.S. Coutinho 78; k-1. D. Araújo 1980; m. J.D. García G. 1467; n-o. D. Cavalcanti 609). 
Material examinado selecionado: Mata de Chave, 28.I.2016, fl., T.S. Coutinho et al. 127 (UFP); Mata Dedo de Deus, 30.VI.2016. fl. e fr., T.S. Coutinho et al. 143 (UFP); Mata dos Macacos, 4.VIII.2015, fl., T.S. Coutinho et al. 26 (UFP); Mata de Pezinho, 4.X.2007, fl., A. Alves-Araújo et al. 580 (UFP); Mata de Piedade, 22.III.2007, fl., A. Alves-Araújo et al. 192 (UFP); Mata das Vespas, 12.III.2009, fl., J.D. García-Gonzalez et al. 981 (UFP); Mata de Zambana, 10.IX.2015, fl., T.S. Coutinho et al. 74 (UFP).

Distribui-se pela Venezuela, Colômbia, Bolívia, Guiana, Suriname e Brasil (Govaerts \& Leeuwenberg 2016), em todas as regiões, habitando a Amazônia, Caatinga, Cerrado e Mata Atlântica (BFG 2015). Na área de estudo Mandevilla scabra ocorre em bordas de mata e está bem representada na maioria dos fragmentos estudados. Assemelhase a Mandevilla hirsuta, diferindo desta pelas sépalas menores (ca. 2,2 vs. 5,4-6,2 mm compr.) e pelos frutos glabros ( $v s$. híspidos).

Matelea Aubl., Hist. Pl. Guiane 277-278, pl. 109, f. 1.1775 .

Trepadeiras herbáceas ou lenhosas; látex alvo. Ramos lenticelados ou não, coléteres interpeciolares ausentes ou presentes, intrapeciolares presentes. Folhas opostas, discolores; lâmina com um 1 par de coléteres na base da face adaxial; venação broquidódroma. Brácteas escariosas. Sépalas com coléteres alternos na base da face adaxial. Corola rotácea. Estames adnatos à cabeça estigmática. Ovário ovoide, glabro; nectário ausente. Ginostégio de ápice truncado.

10. Matelea ganglinosa (Vell.) Rapini, Neodiversity 3: 19. 2008.

Fig. $2 \mathrm{~h}-\mathrm{j}$

Trepadeiras lenhosas. Ramos tomentosos, coléteres interpeciolares ausentes. Pecíolo 1,7-5,9 cm compr., pubescente. Lâmina foliar 4,3-11,5 × 2,4-8 cm, cordiforme, membranácea a cartácea, base cordada, margens levemente revolutas, ápice acuminado, face adaxial pubescente, abaxial lanosa. Umbelas laterais, ca. 4 flores; bráctea ca. $6 \times 1 \mathrm{~mm}$, serícea; apenduncular; pedicelo ca. 0,2 cm compr., seríceo. Sépalas 3-3,6 × 1,2-1,6 mm, lanceoladas, ápice agudo, pilosas externamente. Corola esverdeada a amarronzada, pilosa; tubo ca. 5 mm compr.; lobos 4-4,5 × 3-3,5 mm, lanceolados, papilosos. Corona simples, anelar, sinuosa, ca. 2 mm compr., glabrescente. Anteras ca. $0,8 \times 1,5 \mathrm{~mm}$; apêndice membranáceo não observado. Retináculo 0,1-0,2 mm compr.; caudículas ca. 0,1 mm compr.; polínias ca. $0,8 \times 0,4 \mathrm{~mm}$, inseridas lateralmente às caudículas. Ovário 1,6-2 × 1,7 mm; ginostégio ca. 1,2 mm compr, levemente depresso. Frutos folículos, 7,5-8,5 × 3-3,5 cm, tomentoso, com projeções filiformes. Sementes comosas, 0,5-0,6 cm compr., coma alva.

Material examinado: Alojamento, 10.IX.2015, fl. e fr., T.S Coutinho et al. 78 (UFP); 12.XI.2015, fl. e fr., T.S Coutinho et al. 89 (UFP); Mata dos Macacos, 6.VII.2007, fl., J.S. Marques \& N.A. Albuquerque 180 (IPA); Mata de Pezinho, 4.X.2007, fr., A. Alves-Araújo et al. 601 (UFP); Mata de Piedade, 9.VIII.2007, est., D. Araújo et al. 405 (UFP); 9.VIII.2007, fl. e fr., J.S. Marques 243 (IPA); 14.IX.2009, fr., J.D. García G. \& K. Rajput 1165 (UFP).

Endêmica do Brasil, distribui-se nas regiões Nordeste e Sudeste (BFG 2015; Rapini \& Farinaccio 2008), habitando a Caatinga e Mata Atlântica (BFG 2015). Na USJ Matelea ganglinosa ocorre em bordas de mata e difere de $M$. orthosioides principalmente pela lâmina foliar indumentada (vs. glabra) e cordiforme (vs. elíptica), e representa um novo registro para a área de estudo. Para Rapini (2010), M. ganglinosa assemelha-se a $M$. maritima (Jacq.) Woodson, esta restrita ao Norte do país, diferindo pelo ápice do ginostégio truncado, levemente depresso ( $v s$. conspicuamente rostrado) e frutos com projeções filiformes ( $v s$. muricados).

11. Matelea orthosioides (E. Fourn.) Fontella, Bradea 4(9): 55.1984.

Fig. 2k-1

Trepadeiras herbáceas. Ramos glabrescentes, inconspicuamente lenticelados, coléteres interpeciolares presentes. Pecíolo $0,4-1,1 \mathrm{~cm}$, glabrescente. Lâmina foliar 2,7-9,5 × 1,6-4 cm, elíptica, membranácea a cartácea, base aguda, margens levemente revolutas, ápice acuminado, glabra em ambas as faces, mas glabrescente ao longo da nervura primária na face adaxial. Cimeiras laterais, 2-3 flores; bráctea ca. 2,5 × 0,5 mm, glabrescente; pedúnculo ca. $0,2 \mathrm{~cm}$ compr., glabro a glabrescente; pedicelo $0,2-0,5 \mathrm{~cm}$ compr., glabro a glabrescente. Sépalas ca. $2 \times 1 \mathrm{~mm}$, ovadas, ápice agudo, externamente escabras. Corola verde, glabra; tubo ca. $0,5 \mathrm{~mm}$ compr.; lobos ca. $4 \times 2 \mathrm{~mm}$, ovados, face abaxial glabra a glabrescente, adaxial glabra, subpatentes a reflexos. Corona inconspícua, ca. $1 \mathrm{~mm}$ compr. Anteras ca. 0,5 mm compr., apêndice membranáceo não observado. Retináculo 0,1-0,2 mm compr.; caudículas ca. 0,1 mm compr.; polínias $0,4 \times 0,2 \mathrm{~mm}$, inseridas apicalmente às caudículas. Ovário ca. $1 \times 0,8 \mathrm{~mm}$; ginostégio ca. $0,5 \mathrm{~mm}$ compr. Frutos não observados.

Material examinado: Mata dos Macacos, 23.XII.2011, fl., D. Araújo et al. 1980 (JPB); Mata de Zambana, 19.X.2007, fl., A. Alves-Araújo et al. 667 (UFP); 22.XII.2007, fl., B.S. Amorim et al. 218 (UFP). 
No Brasil ocorre na Região Norte, Nordeste, Centro-Oeste, Sudeste e no Paraná na região Sul, habitando a Amazônia, Caatinga, Cerrado e Floresta Atlântica (BFG 2015). Na USJ Matelea orthosioides ocorre apenas em bordas de mata e pode ser distinta de $M$. ganglinosa pela lâmina foliar glabra ( $v s$. indumentada) e elíptica ( $v s$. cordadas). A espécie representa neste estudo um novo registro para a Usina São José.

12. Odontadenia lutea (Vell.) Markgr., Repert. Spec. Nov. Regni Veg. 20:24.1924. Fig. 2m-o

Trepadeiras lenhosas; látex alvo. Ramos glabros, lenticelas verrucosas, coléteres inter e intrapeciolares presentes. Folhas opostas; pecíolo 1,7-2,3 cm compr., glabro; lâmina 14,2-20 × $4,2-6,8 \mathrm{~cm}$, elíptica, membranácea, base atenuada, margens planas, ápice acuminado a caudado, glabra em ambas as faces, coléteres ausentes; venação broquidódroma. Cimeiras laterais, ca. 13 flores; bráctea escariosa, 3-6 × 2-3 mm, glabra; pedúnculos ca. $3 \mathrm{~cm}$ compr., glabros; pedicelo 1-2 cm compr., glabro. Sépalas 8-11 × $6 \mathrm{~mm}$, lanceoladas a ovadas, ápice arredondado, externamente glabras, coléteres alternos na base da face interna. Corola alva a esverdeada, infundibuliforme, glabra; tubo inferior 20-22 mm compr., tubo superior 17-22 × 17-18 mm; lobos ca. $17 \times 15 \mathrm{~mm}$, amplamente ovados. Estames adnatos à cabeça estigmática. Anteras ca. $8 \mathrm{~mm}$ compr., base sagitada, dorso pubescente. Ovário ca. 1,8 $\times 2 \mathrm{~mm}$, ovoide, glabro; nectários-5, ca. 2,2 $\mathrm{mm}$ compr., anelares; estilete ca. $25 \mathrm{~mm}$ compr.; cabeça estigmática ca. $2 \mathrm{~mm}$ compr., fusiforme, ápice piloso. Frutos folículos 16-17 × 1,5 cm, glabros, divergentes.

Material examinado: Mata de Piedade, 9.III.2010, est., J.D. García G. 1467 (UFP).

Material adicional examinado: BRASIL. PERNAMBUCO: Goiana, RPPN Fazenda Tabatinga, 14.X.2011, fl. e fr., D. Cavalcanti et al. 609 (UFP); Itamaracá, 19.IX.1989, fl., D. Belo 191 (IPA).

Ocorre no Brasil, Bolívia e Peru (Morales 1999). No Brasil, distribui-se pelas regiões Norte, na Bahia no Nordeste, Centro-Oeste e Sudeste, habitando a Amazônia, Caatinga, Cerrado e Floresta Atlântica (BFG 2015). Na USJ Odontadenia lutea ocorre em áreas de tabuleiro e é reconhecida pelos seus ramos com lenticelas verrucosas e flores com corola infundibuliforme, alva e bem vistosas. Representa neste estudo um novo registro para Pernambuco.
Rauvolfia L., Sp. Pl. 1: 208. 1753.

Arbustos 1-4 m alt.; látex alvo. Ramos lenticelados ou não, coléteres interpeciolares ausentes ou presentes, coléteres intrapeciolares presentes. Folhas verticiladas, sésseis a subsésseis, discolores; lâmina sem coléteres; venação broquidódroma. Brácteas escariosas. Sépalas sem coléteres. Corola hipocrateriforme. Estames livres da cabeça estigmática; anteras de base cordada, glabras. Ovário ovoide ou globoso, glabro; nectário anelar; cabeça estigmática cilíndrica.

13. Rauvolfia grandiflora Mart. ex. A.DC., Prodr. 8: 341.1844.

Fig. 3a

Arbustos 1-4 m alt. Ramos glabros, pouco lenticelados, coléteres interpeciolares presentes. Folhas 4 por nó, congestas no ápice dos ramos; pecíolo ca. $0,2 \mathrm{~cm}$ compr., glabro; lâmina 5,6-11,3 $\times 2-4 \mathrm{~cm}$, oblanceolada a elíptica, membranácea, base atenuada, margens levemente revolutas, ápice acuminado, glabra em ambas as faces. Cimeiras terminais, 10-15 flores; bráctea 1,4-2 × 0,9-1 $\mathrm{mm}$, glabra a glabrescente; pedúnculo 1,5-3,6 $\mathrm{cm}$, glabro; pedicelo $0,8-1,3 \mathrm{~cm}$ compr., glabro. Sépalas $1,8-1,9 \times 1,1 \mathrm{~mm}$, triangulares, ápice agudo, externamente glabras. Corola alva com face adaxial dos lobos roxa, glabra; tubo ca. $28 \mathrm{~mm}$ compr.; lobos ca. $7 \times 2,5 \mathrm{~mm}$, lanceolados, glabros. Anteras 1,9-2,2 mm compr. Ovário ca. $2 \times 1,5$ mm compr., ovoide; nectário ca. 1,2 mm compr.; estilete ca. 0,8 cm compr.; cabeça estigmática ca. $1,2 \mathrm{~mm}$ compr., parte mediana mais dilatada, ápice inconspicuamente bilobado. Frutos drupas, 2-2,5 $\times$ $1,5-2 \mathrm{~cm}$, globosas ou cordadas, glabras.

Material examinado selecionado: Capoeira, 17.VII.2008, fr., L.M. Nascimento \& G. Batista 758 (UFP); Engenho Campinas, 29.IV.2009, fl., L.M. Nascimento \& G. Batista 745 (UFP); Mata de Pezinho, 28.IV.2009, f1., T.A. Pontes 179 (JPB, MAC, UFP); 12.XI.2015, fl. e fr., T.S. Coutinho et al. 142 (UFP); Mata de Piedade, 24.I.2004, fl. e fr., I.M.M. Sá e Silva et al. 275 (PEUFR); 21.XI.2008, fl. e fr., A.C.B. Lins \& M.A. Chagas 377 (UFP, MAC); 19.VIII.2009, fl., J.D. García G. 1222 (JPB, UFP).

Endêmica do Brasil e da Floresta Atlântica, ocorrendo nas regiões Nordeste e Sudeste (BFG 2015; Govaerts \& Leeuwenberg 2016). Na USJ Rauvolfia grandiflora ocorre nas bordas e interior de mata, em áreas de tabuleiros e declive, e pode ser diferenciada de $R$. ligustrina pelo pecíolo sem coléteres (vs. coléteres ao longo do sulco peciolar), pelas folhas verticiladas 4 por nó ( $v s .3$ por nó) e pelas flores com tubo de comprimento maior (ca. 28 vs. $2,8 \mathrm{~mm}$ compr.) 


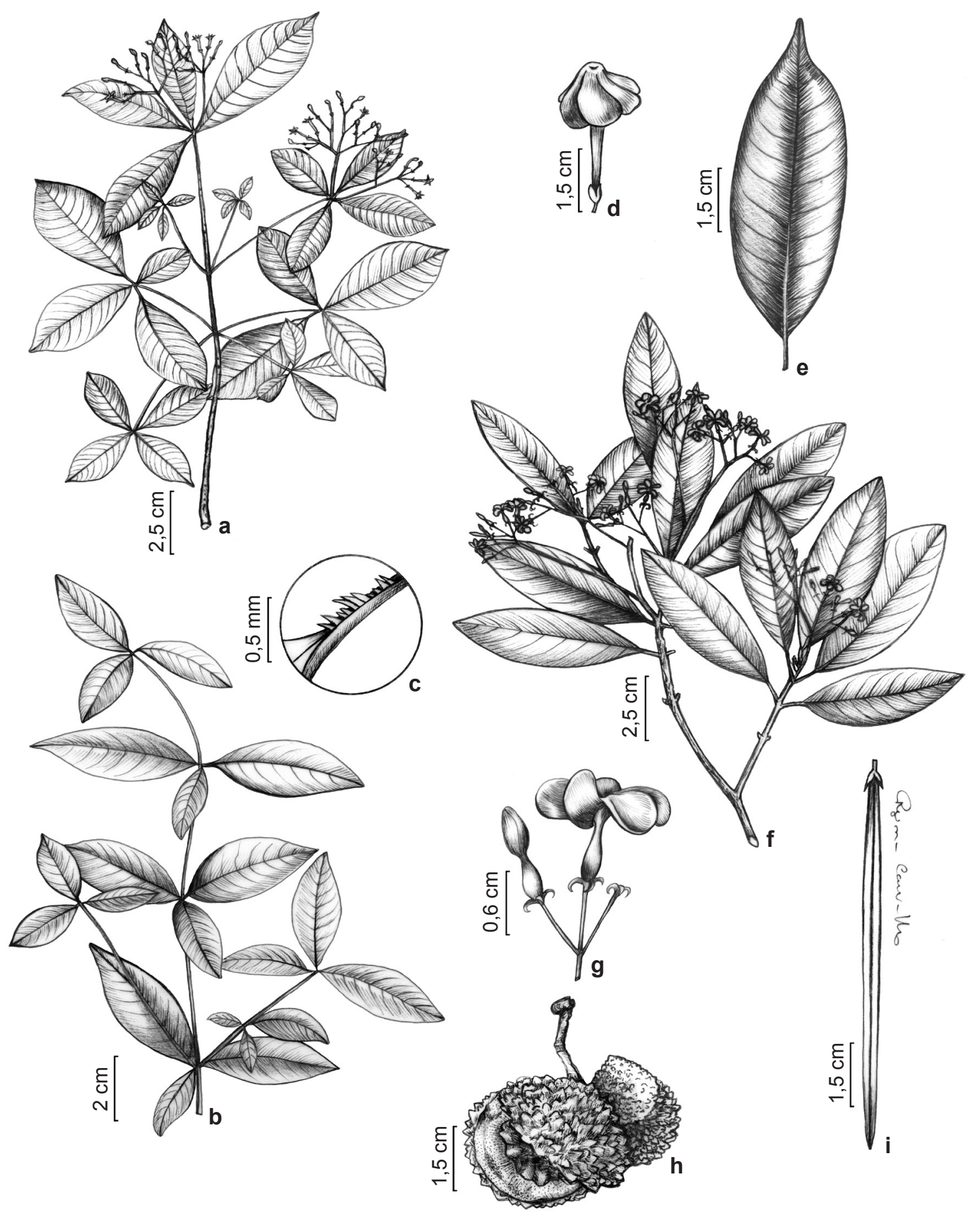

Figura 3 - a. Rauvolfia grandiflora - hábito. b-c. Rauvolfia ligustrina - b. hábito; c. detalhe do pecíolo com coléteres. d-e. Tabernaemontana flavicans - d. flor; e. folha. f-h. Tabernaemontana salzmannii - f. hábito com flores; g. flor e botão; h. fruto. i. Temnadenia odorifera - fruto. (a. T.S. Coutinho 142; b-c. L.M. Nascimento 765; d-e. J.D. García-Gonzalez 1155; f-h. T.S. Coutinho 82; i. T.S. Coutinho 130).

Figure 3 - a. Rauvolfia grandiflora - habit. b-c. Rauvolfia ligustrina - b. habit; c. detail of the petiole with colleters. d-e. Tabernaemontana flavicans - d. flower; e. leaf. f-h. Tabernaemontana salzmannii - f. habit with flowers; g. flower and flower bud; h. fruit. i. Temnadenia odorifera - fruit. (a. T.S. Coutinho 142; b-c. L.M. Nascimento 765; d-e.J.D. García-Gonzalez 1155; f-h. T.S. Coutinho 82; i. T.S. Coutinho 130). 
14. Rauvolfia ligustrina Willd. ex Roem. \& Schult., Syst. Veg. (ed. 15 bis) 4: 805. 1819.

Fig. 3b-c

Arbustos ca. $1 \mathrm{~m}$ alt. Ramos glabros, coléteres interpeciolares ausentes. Folhas 3 por nó, dispostas ao longo dos ramos; pecíolo $0,1-0,3 \mathrm{~cm}$, glabro, coléteres ao longo do pecíolo; lâmina 2,8-7,6 $\times$ 1,8-3,6, elíptica, membranácea, base atenuada, margens planas, ápice acuminado, glabra em ambas as faces, com nervura principal da face abaxial esparsamente pubescente. Cimeiras terminais, ca. 6 flores; bráctea $0,8-2 \times 0,3-0,5 \mathrm{~mm}$, glabra a glabrescente; pedúnculo ca. $0,7 \mathrm{~cm}$ compr.; pedicelo ca. 2,8 mm compr., glabro. Sépalas ca. $1 \times 0,6$ $\mathrm{mm}$, triangulares, ápice acuminado, externamente glabras, mas pouco ciliadas na base. Corola alva, glabra; tubo ca. $2,8 \times 0,8 \mathrm{~mm}$; lobos ca. $1 \times 0,8$ $\mathrm{mm}$, arredondados. Anteras ca. 0,6 mm compr. Ovário $0,8 \times 0,7 \mathrm{~mm}$, globoso; nectário ca. $0,4 \mathrm{~mm}$ compr.; cabeça estigmática ca. $0,4 \times 0,4 \mathrm{~mm}$, ápice inconspicuamente bilobado. Frutos não observados. Material examinado: Engenho Campinas, Capoeira, 17.XI.2008, bf., L.M. Nascimento et al. 765 (UFP).

Material adicional examinado: BRASIL. PERNAMBUCO: Recife, Cidade Universitária, 16.XI.1972, fl., J.C. de Souza (UFP 3777).

Amplamente distribuída na América Central, Norte e Nordeste da América do Sul com área disjunta na Bolívia, Brasil e Paraguai (Govaerts \& Leeuwenberg 2016). No Brasil ocorre no Amazonas e Pará na Região Norte, além das regiões Nordeste, Centro-Oeste e no Rio de Janeiro no Sudeste, habitando os domínios Amazônico, do Cerrado, Caatinga e Floresta Atlântica (BFG 2015). Na USJ Rauvolfia ligustrina ocorre no interior de mata, em hábitats de tabuleiro e áreas de declive, e pode ser diferenciada de $R$. grandiflora pelo pecíolo com coléteres ( $v s$. sem coléteres), pelas folhas verticiladas 3 por nó (vs. 4 por nó) e pela corola com tubo de menor comprimento (ca. 2,8 $\mathrm{mm}$ vs. $28 \mathrm{~mm}$ compr.).

Tabernaemontana L., Sp. Pl. 1: 210. 1753.

Arbustos, arvoretas ou árvores; látex alvo, abundante. Ramos não lenticelados, coléteres interpeciolares ausentes, intrapeciolares ausentes ou presentes. Folhas opostas, discolores; lâmina sem coléteres; venação camptódroma ou broquidódroma. Brácteas escariosas. Sépalas com coléteres opostos na base da face adaxial. Corola hipocrateriforme. Estames livres da cabeça estigmática; anteras glabras. Ovário ovoide, glabro ou glabrescente; nectário ausente; cabeça estigmática cilíndrica.
15. Tabernaemontana flavicans Willd. ex Roem. \& Schult., Syst. Veg. (ed. 15 bis) 4: 797. 1819.

Fig. 3d-e

Arbustos ou arvoretas 2-3 m alt. Ramos glabros. Folhas dispostas ao longo dos ramos; pecíolo $0,4-0,9 \mathrm{~cm}$ compr., glabro, coléteres intrapeciolares ausentes; lâmina 5,2-14 × 1,7-5,5 $\mathrm{cm}$, estreito-elíptica, membranácea a cartácea, base cuneada, margens planas, ápice cuspidado, ambas as faces glabras; venação broquidódroma. Cimeiras laterais ou terminais, 3-4 flores; pedúnculo ca. 0,3 cm compr., glabro; bráctea ca. 1,5-2 × 1-1,5 mm, ovada, ápice agudo, glabra; pedicelo $0,9-1,7 \mathrm{~cm}$ compr., glabro. Sépalas 3-4 × 2,5-2,7 mm, ovadas, ápice subagudo ou arredondado, externamente glabras, margens as vezes pouco ciliadas na base. Corola alva, fauce amarelada, glabra; tubo 17-26 mm compr.; lobos ca. $18 \times 6 \mathrm{~mm}$. Anteras 5-5,5 $\times$ $1 \mathrm{~mm}$, base sagitada. Ovário ca. $3 \times 1 \mathrm{~mm}$, glabro; estilete ca. 1,2 cm compr.; cabeça estigmática ca. $1 \mathrm{~mm}$ compr., base alargada, com pequenas protuberâncias, apêndices apicais-2. Frutos não observados.

Material examinado: Mata de Chave, 23.VIII.2008, fl., T.N.F. Guerra et al. 222 (UFP); Mata dos Macacos, 16.VIII.2007, fl., D. Araújo et al. 429 (UFP); Mata de Piedade, 29.VII.2007, bot., A. Alves-Araújo et al. 488 (UFP); 9.VIII.2007, fl., A. Alves-Araújo et al. 500 (UFP); 20.VIII.2009, fl., J.D. García G. 1155 (JPB, UFP); 12.IX.2007, fl., A. Melo et al. 145 (UFP); Mata de Zambana, 4.IX.2007, fl., A. Alves-Araúijo et al. 547 (UFP); fl., N.A. Albuquerque et al. 471 (IPA).

Distribui-se pela Venezuela, Colômbia, Peru e Brasil (Govaerts \& Leeuwenberg 2016). No Brasil ocorre no Norte, Nordeste, Centro-Oeste e Sudeste (BFG 2015). Na USJ Tabernaemontana flavicans ocorre em bordas e interior de mata, em hábitats de tabuleiros, e diferencia-se de $T$. salzmannii pelas folhas de ápice cuspidado ( $v s$. agudo), sépalas eretas ( $v s$. reflexas) e tubo da corola de maior comprimento (17-26 vs. 10-12 mm).

16. Tabernaemontana salzmannii A. DC., Prodr. 8: 362.1844.

Fig. 3f-h

Árvores ou arbustos 2-6 m alt. Ramos glabros, coléteres intrapeciolares presentes. Folhas congestas no ápice dos ramos; pecíolo ca. 1,2 cm compr., glabro a glabrescente; lâmina 4-12 × 2-3,7 cm, cartácea, estreito-elíptica, base cuneada, margens planas, revolutas, ápice agudo, glabra em ambas as faces; venação camptódroma. Cimeiras terminais, 10-18 flores; bráctea 1-1,2 mm compr., glabra; pedúnculo ca. $0,3 \mathrm{~cm}$ compr., glabro; pedicelo ca. 1,4 cm compr., glabro. 
Sépalas 3-5,8 $\times 2 \mathrm{~cm}$, ovadas, ápice obtuso a subagudo, externamente glabras. Corola alva, glabra; tubo 10-12 mm compr.; lobos ca. $15 \times 14$ $\mathrm{mm}$, dolabriformes. Anteras 4,3-4,5 mm compr., base sagitada. Ovário 2,2-2,5 mm compr., glabro, glabrescente na região mediana onde os carpelos se tocam; estilete 1,2-1,6 mm compr.; cabeça estigmática 2-2,2 mm compr., base com projeções ao seu redor, ápice subcostado, apêndices apicais-2. Frutos folículos 4,7-5 $\times 4 \mathrm{~cm}$, glabros, muricados. Sementes ariladas, ca. 1,5 ×0,6 cm, glabras, arilo laranja.

Material examinado selecionado: Mata de BR, 23.VIII.2008, fl., P.G.A. Mendes et al. 58 (UFP); Mata de Pezinho, 2.III.2009, fl., A. Alves-Araújo \& A. Melo 1182 (UFP); Mata de Piedade, 6.V.2009, fr., T.A. Pontes 191 (MAC, UFP); 20.X.2015, fl. e fr., T.S. Coutinho et al. 82 (UFP); Mata da Usina São José, 14.X.2003, fl., H.C.H. Silva \& J.S. Gomes 307 (UFP); Mata da Usina São José/ Mata de Piedade, 14.X.2003, fl., I.M.M. Sá e Silva \& S.G. Freire 187 (UFP); Mata de Zambana, 13.X.2008, fl., M.A.M. Silva et al. 132 (UFP); N.A. Albuquerque et al. 478 (IPA).

Endêmica do Brasil, ocorrendo nos estados de Pernambuco, Alagoas, Bahia e Espírito Santo, habitando os domínios do Cerrado e Floresta Atlântica (BFG 2015; Leeuwenberg 1994). Na USJ Tabernaemontana salzmannii ocorre em bordas de mata, e difere de $T$. flavicans pelas folhas de ápice agudo ( $v s$. cuspidado), sépalas reflexas ( $v s$. eretas) e flores com tubo da corola de menor comprimento (10-12 vs. 17-26 mm).

17. Temnadenia odorifera (Vell.) J.F. Morales, Novon 9(2): 240. 1999. Fig. $3 \mathrm{i}$

Trepadeiras lenhosas; látex incolor, ralo. Ramos glabrescentes a estrigosos, coléteres inter e intrapeciolares presentes. Folhas opostas, discolores; pecíolo 0,3-0,7 cm compr., pubescente a piloso; lâmina 4,4-9,2 × 2,4-5,2 cm, ovada, cartácea, base arredondada a cordada ou subcordada, margens levemente revolutas, ápice acuminado, face adaxial estrigosa ou escabra, face abaxial estrigosa a tomentosa, coléteres ausentes; venação broquidódroma. Racemos terminais ou laterais, 9-18 flores; bráctea escariosa, ca. $3 \times 0,5$ $\mathrm{mm}$, pilosa; pedúnculo 1,4-6,5 cm compr., lanoso ou piloso; pedicelo $0,5-1,4 \mathrm{~cm}$ compr., escabro a lanoso. Sépalas $4-5 \times 1,8-4 \mathrm{~mm}$, triangulares, ápice agudo, externamente esparsamente estrigosas. Corola lilás a rosada, fauce creme, hipocrateriforme, glabra; tubo 1,4-3,2 cm compr.; lobos ca. $15 \times 25$ $\mathrm{mm}$, transversalmente elípticos. Estames adnatos à cabeça estigmática; anteras ca. $8 \mathrm{~mm}$ compr., base sagitada, puberulentas dorsalmente. Ovário 1,8-2,3 × $2 \mathrm{~mm}$, ovoide, glabro; nectários-5, 1,7-3 mm compr., anelar; estilete $12-17 \mathrm{~mm}$; cabeça estigmática $1,5-2 \mathrm{~mm}$, cilíndrica, base alargada, anelar. Frutos folículos-2, 14-17 cm, unidos longitudinalmente, glabros. Sementes não observadas.

Material examinado: Mata de Chave, 24.XI.2009, fl., E. Pessoa \& J.A.N. Souza 143 (JPB, UFP); 28.I.2016, fl. e fr., T.S. Coutinho et al. 130 (UFP); Engenho Campinas, 13.III.2009, fl., L.M. Nascimento \& G. Batista 790 (UFP, MAC); Fragmento da Usina São José, 20.XI.2008, fl., K. Mendes et al. 261 (UFP); Mata de Pezinho, 9.V.2007, fl., A. Alves-Araújo et al. 228 (UFP); 11.I.2008, fr., D. Araújo et al. 610 (UFP); Mata das Vespas, 28.I.2010, fl., D. Cavalcanti et al. 138 (UFP); Mata de Zambana, 13.III.2009, fl., J.D. García G et al. 1000 (UFP).

Endêmica do Brasil (BFG 2015; Morales 2005), onde ocorre no Nordeste, Sudeste e Sul (BFG 2015). Embora citada como endêmica da Floresta Atlântica (BFG 2015), Quinet \& Andreata (2005) a mencionaram também para áreas de Caatinga. Na USJ Temnadenia odorifera ocorre em bordas e interior de mata, em hábitats de tabuleiros, e pode ser reconhecida na área pelo seu látex incolor, corola hipocrateriforme de cor rosa a lilás com fauce creme e pelos folículos geminados unidos longitudinalmente.

\section{Agradecimentos}

Os autores agradecem à Capes, a bolsa concedida ao primeiro autor; ao CNPq, U.S. National Science Foundation, Velux Stiftung, Beneficia Foundation e BMBF, o apoio financeiro; aos curadores dos herbários visitados, em especial a Marlene Barbosa (UFP-UFPE), a Regina Carvalho, as perfeitas ilustrações e à equipe do Laboratório de Morfo-taxonomia Vegetal.

\section{Referências}

Alves-Araújo A, Araújo D, Marques J, Melo A, Maciel JR, Uirapuã J, Pontes T, Lucena MFA, Bocage ALD \& Alves M (2008) Diversity of angiosperms in fragments of Atlantic Forest in the state of Pernambuco, northeastern Brazil. Bioremediation, Biodiversity and Bioavailability 2: 14-26.

Alves-Araújo A \& Alves M (2010) Flora da Usina São José, Igarassu, Pernambuco: Sapotaceae. Rodriguésia 61: 303-318.

Alves M, Alves-Araújo A, Amorim B, Araújo A, Araújo D, Araujo MF, Buril MT, Costa-Lima J, GarciaGonzalez J, Gomes-Costa G, Melo A, Novaes J, Oliveira S, Pessoa E, Pontes T \& Rodrigues J (2013) Inventário de Angiospermas dos fragmentos 
de Mata Atlântica da Usina Sao José, Igarassu, Pernambuco. In: Buril MT, Melo A, Alves-Araújo A \& Alves M (eds.) Plantas da Mata Atlantica: guia de árvores e arbustos da Usina São José (Pernambuco). Ed. Livro Rápido, Recife. Pp.133-158.

APG IV - Angiosperm Phylogeny Group (2016) An update of the Angiosperm Phylogeny Group classification for the orders and families of flowering plants: APG IV. Botanical Journal of the Linnean Society 181: 1-20.

BFG - The Brazil Flora Group (2015) Growing knowledge: an overview of seed plant diversity in Brazil. Rodriguésia 66: 1085-1113.

Costa-Lima JL \& Alves M (2015) Flora da Usina São José, Igarassu, Pernambuco: Erythroxylaceae. Rodriguésia 66: 1-11.

Farinaccio MA, Simões AO, Vale CO, Campos DA, Koch I, Morales JF \& Konno T (2013) Apocynaceae. In: Prata APN, Amaral MCV, Farias MCV \& Alves MV (orgs.) Flora de Sergipe. Universidade Federal de Sergipe. Ed. Triunfo, Aracaju. Pp. 45-95.

Fontella-Pereira J, Valente MC \& Silva NMF (1995) Flora da Serra do Cipó, Minas Gerais: Asclepiadaceae. Bol. Bot. Univ. São Paulo 14: 131-179.

Govaerts R \& Leeuwenberg A (2016). World checklist of Apocynaceae. The Board of Trustees of the Royal Botanic Gardens, Kew. Disponível em $<$ http://apps. kew.org/wcsp/>. Acesso em 11 fevereiro 2016.

Harris J \& Harris M (2001) Plant identification terminology - an illustrated glossary. $2^{\mathrm{a}}$ ed. Spring Lake Publishing, Payson. 260p.

Hickey LJ (1973) Classification of architecture of dicotyledonous leaves. American Journal of Botany 60: $17-33$.

Joly AB (1979) Botânica: introdução à taxonomia vegetal. 13 ${ }^{\text {a }}$ ed. Cia. Editora Nacional, São Paulo. $777 \mathrm{p}$.

Köppen W (1936) Das geographische System der Klimate. In: Köppen W \& Geiger W (eds.) Handbuch der Klimatologie. Bd. I, Teil C, Kraus Verlag, Nendeln. Pp. 1-43.

Luna NK, Pessoa E \& Alves M (2016) Flora da Usina São José, Igarassu, Pernambuco: Zingiberales. Rodriguésia 67: 261-273.

Kinoshita LS \& Simões AO (2005) Flora da Serra do Cipó, Minas Gerais: Apocynaceae s.str. (Apocynoideae e Rauvolfioideae). Boletim de Botânica da Universidade de São Paulo 23: 235 256.

Koch I \& Kinoshita LS (1999) As Apocynaceaes. str. na região de Bauru, São Paulo, Brasil. Acta Botanica Brasilica 13: 61-86.

Leeuwenberg AJM (1994)Arevision of Tabernaemontana two. The new world species and Stemmadenia. Series of revision of Apocynaceae: XXXVI. Royal Botanic Gardens, Kew. 450p.
Maciel JR \& Alves M (2014) Flora da Usina São José, Igarassu, Pernambuco: Poaceae. Rodriguésia 65: 355-367.

Matozinhos CN \& Konno TUP (2011) Diversidade taxonômica de Apocynaceae na Serra Negra, MG, Brasil. Hoehnea 38: 569-595.

Marcondes-Ferreira Neto W (1988) Aspidosperma Mart., nom. cons. (Apocynaceae): estudos taxonômicos. Tese de Doutorado. Universidade Estadual de Campinas, Campinas. 431p.

Monguilhott L \& Mello-Silva R (2008) Apocynaceae do Parque Estadual de Ibitipoca, Minas Gerais, Brasil. Boletim de Botânica 26: 93-130.

Morales JF (1999) A synopsis of the genus Odontadenia series of revisions of Apocynaceae XLV. Bulletin du Jardin Botanique National de Belgique/Bulletin van de National Plantentuin 67: 381-477.

Morales JF (2005) Estudios en las Apocynaceae Neotropicales XIII : revisión del género Temnadenia (Apocynoideae, Echiteae). Candollea 60: 207-231.

Morales JF (2007) Estudios en las Apocynaceae neotropicales xxxi: el complejo de Mandevilla hirsuta y cuatro nuevas especies. Journal of the Botanical Research Institute of Texas 1: 859-869.

Mori SA, Mattos-Silva LA, Lisboa G \& Coradin L (1985) Manual de manejo do herbário fanerogâmico. Centro de Pesquisas do Cacau, Ilhéus. 97p.

Pessoa E \& Alves M (2012) Flora da Usina São José, Igarassu, Pernambuco: Orchidaceae. Rodriguésia 63: $341-356$

Quinet CGP \& Andreata RHP (2005) Estudo taxonômico e morfológico das espécies de Apocynaceae Adans. na reserva Rio das Pedras, Município de Mangaratiba, Rio de Janeiro, Brasil. Pesquisas, Botânica 56: 13-73.

Radford AE, Dickison WC, Massey JR \& Bell CR (1974) Vascular plant systematics. University of North Carolina, New York. 891p.

Rapini A (2010) Revisitando as Asclepiadoideae (Apocynaceae) da Cadeia do Espinhaço. Boletim de Botânica 28: 97-123.

Rapini A, Mello-Silva R \& Kawasaki ML (2001) Asclepiadoideae (Apocynaceae) da Cadeia do Espinhaço de Minas Gerais, Brasil. Boletim de Botânica da Universidade de São Paulo 19: 55-169.

Rapini A, Mello-Silva R \& Kawasaki ML (2003) Flora de Grão-Mogol: Apocynaceae II (Asclepiadoideae). Boletim de Botânica da Universidade de São Paulo 21: 83-96.

Rapini A \& Farinaccio MA (2008) Two taxonomic changes in Asclepiadoideae (Apocynaceae) from Brazil. Neodiversity 3: 19-21.

Sennblad B \& Bremer B (2002) Classification of Apocynaceae s.l. according to a new approach combining Linnaean and phylogenetic taxonomy. Systematic Biology 51: 389-409. 
Silva AG, Sá-e-Silva IMM, Rodal MJN \& Lins-e-Silva AC (2008) Influence of edge and topography on canopy and sub-canopy structure of an Atlantic Forest fragment in Igarassu, Pernambuco State, Brazil. Bioremediation, Biodiversity and Bioavailability 2: 41-46.

Souza VC \& Lorenzi H (2012) Botânica sistemática: guia ilustrado para identificação das famílias de fanerógamas nativas e exóticas no Brasil, baseado em APG III. $3^{\text {a }}$ ed. Instituto Plantarum, São Paulo. 768p.

Thiers B [continuamente atualizado] Index herbariorum: a global directory of publich herbaria and associated staff. New York Botanical Garden's Virtual
Herbarium. Disponível em $<$ http://sweetgum.nybg. org/science/ih/>. Acesso em 10 outubro 2015.

Trindade MB, Lins-e-Silva ACB, Silva HP, Figueira SB \& Schessl M (2008) Fragmentation of the Atlantic rainforest in the northern coastal region in Pernambuco, Brazil: recent changes and implications for conservation. Bioremediation, Biodiversity and Bioavailability 2: 5-13.

Watanabe MTC, Roque N \& Rapini A (2009) Apocynaceae sensu strictum no Parque Municipal de Mucugê, Bahia, Brasil, incluindo a publicação válida de dois nomes em Mandevilla Lindl. Iheringia 64: 63-75.

\section{Lista de exsicatas}

Albuquerque L 19 (8). Albuquerque NA 201 (6), 462 (8), 471 (15), 478 (16). Alves-Araújo A 192 (9), 228 (17), 488 (15), 500 (15), 547 (15), 553 (8), 580 (9), 601 (10), 650 (7), 667 (11), 896 (5). Alves-Araújo A \& Marques JS 859 (5). Alves-Araújo A \& Melo A 1182 (16). Amorim BS 218 (11). Antônio M s.n. IPA 78431. (13) Araújo D 405 (10), 428 (9), 429 (15), 444 (13), 610 (17), 1978 (6), 1980 (11). Belo D 191 (12). Bezerra GJ \& Melquíades A 175 (9). Cavalcanti D 138 (17), 609 (12), 627 (3). Costa TL 10 (6). Coutinho TS 26 (9), 27 (7),28 (6), 29 (6),74 (9), 75 (9), 76 (7), 77 (9), 78 (10), 82 (16), 83 (16), 87 (6), 89 (10), 91 (6), 127a (7), 127b (9),128a (9),128b (7), 129 (6), 130 (17), 142 (13). Cunha LV 313 (6). Leite T 927 (2). García GJD 942 (4), 1000 (17), 1155 (15), 1222 (13), 1467 (12). García GJD \& Rajput K 1165 (10). García-Gonzalez JD 981 (9), 985 (7). Gomes-Costa GA 77 (13). Guerra TNF 222 (15). Lima TV s.n UFP 62554 (1). Lins ACB \& Chagas MA 377 (13). Marques JS 243 (10). Marques JS \& Albuquerque NA 180 (10), 181 (3), 116 (3), 117 (4), 200 (6), 284 (6). Marques JS \& Alves-Araújo A 317 (4). Melo A 02 (6), 63 (9), 145 (15), 209 (9), 207 (7). Melo A \& Albuquerque NA 173 (6). Melo Y 66 (5). Mendes K 261 (17). Mendes PGA 58 (16). Melquíades A \& Bezerra, G.J. 62 (6). Mendes PGA 43 (6), 67 (6). Nascimento LM 642 (6), 671 (6), 765 (14). Nascimento LM \& Batista G 745 (13), 758 (13), 790 (17). Ojima PY 114 (6), 116 (13). Pessoa E 15 (6). Pessoa E \& García, J.D. 266 (9). Pessoa EM \& Souza JAN 143 (17), 118 (6). Pontes TA 179 (13), 191 (16). Sá e Silva IMM 275 (13). Souza JAN 467 (13), 571 (13), 596 (16). Souza JC s.n. UFP 3777. Rocha KD \& Lins e Silva ACB 138 (6). Sá e Silva MA 132 (16). Sá e Silva IMM \& Freire SG 187 (16). Sá e Silva IMM \& Silva MJ 271 (6). Silva MAM 54 (6). Silva Júnior JF 09 (6). Silva HCH 124 (1), 151 (2). Silva HCH \& Lima ALA 119 (6). Silva AG 638 (6). Silva AG \& Sá e Silva IMM 610 (6). Silva HCH \& Gomes JS 307 (16). Silva HCH \& Silva JS 315 (2). Viana JL 18 (16). 